\title{
The Study of English Culture-Specific Items in Persian Translation Based on House's Model: The Case of Waiting for Godot
}

\author{
Elham Shalforoosh Amiri ${ }^{1} \&$ Hossein Heidari Tabrizi ${ }^{2}$ \\ ${ }^{1}$ English Department, Islamic Azad University, Isfahan Branch, Isfahan, Iran \\ ${ }^{2}$ Islamic Azad University, Isfahan Branch, Isfahan, Iran \\ Correspondence: Elham Shalforoosh Amiri, English Department, Islamic Azad University, Isfahan Branch, \\ Isfahan, Iran. E-mail: Eliamiri81@gmail.com; heidaritabrizi@gmail.com
}

\author{
Received: August 3, 2017 Accepted: September 9, 2017 Online Published: October 25, 2017 \\ doi:10.5539/ijel.v8n1p135 URL: https://doi.org/10.5539/ijel.v8n1p135
}

\begin{abstract}
Each society's language differs from other societies' languages; because of the distinctions over the dialects, implications and ideas fluctuate crosswise over two unique dialects. The clearest purposes of distinction between dialects show up in their writing, which contains a lot of culture-specific items (CSIs); this causes some degree of complexities while exchanging implications and ideas from a languege into another. The present study was an attempt to discover proposed interpretation techniques connected in the two translations of Waiting for Godot by Aliakbar Alizad (1385, 2006) and Asgar Rastgar (1393, 2014). There are great differences in the translation. The practice of translators in rendering cultural items of the original reflects their different attitude in the choice of translation strategies The hypothetical structure of this examination depended on the cultural items classification and strategies proposed by Newmark (1988) as well as Houses's (1997) model of translation quality assessment. After extracting cultural items of the original text and their classification, each item was compared and contrasted whit its corresponding rendering in the two translations. The strategies used by translators were then determined. The findings showed that Alizad's work is an overt translation, while Rastgar's work is a covert one. Rastgar's strategies led into great differences with the original. His overuse of informal words and expressions as well as cultural items has domesticated his translation.
\end{abstract}

Keywords: culture, culture specific items, houses model, translation, translation strategies, Waiting for Godot

\section{Introduction}

Obviously, translation strategies play an important role in translating culture-specific items. Because of the significance of interpretation contemplates as a field of concentrate amid the finish of the most recent century and in the recent century, scholars in this field have theorized and developed their models. Certainly, translation strategies will result in different translations due to the different methods of translation. According to House (2009), translation can be defined as a process of replacing a text in one language by its equivalent in another.

It is a kind of secondary communication with both a limiting and enabling function and it is the process of transferring ideas, knowledge and information from one language to another. During the transferring, a few wellsprings of misfortune can be distinguished. The main source can be the loss of meaning, since the meaning of the translation can only be approximately, rather than exactly, the same as that of the original text. The second wellspring of misfortune is identified with the individual employments of dialect by the creators that are identified with their styles. Therefore, the quality of the translation is open to question. This study intended to investigate translation strategies of culture specific items used in two Persian translation of Waiting for Godot by Alizad and Rastgar according to Newmark classification, strategies and House's (1997) Model. House adopted a functional equivalence make conversation whit translation. In other words, the basic idea of translation is that the product should be functionally harmonized with the original text.

Presently in that substructure the thought of secretive interpretation possesses an extraordinary place since undercover interpretations are in reality the main ones satisfactory of really accomplishing the principle objective of the hypothesis, that is, utilitarian proportionality. By method for refinement, the other primary sort of interpretation, called unmistakable interpretation, fundamentally misses the mark regarding this reason. In any case, despite the fact that secret interpretation is the main sort that can really achieve useful identicalness, 
this does not really imply that it can do as such effortlessly, in view of contrasts in the sociocultural foundations of the source and target dialect groups of onlookers. Newmark (1988) additionally arranged the social words as takes after, environment includes: verdure, fauna, slopes, winds, fields. Material culture contains, nourishment, garments, houses and towns transport. Social societies, incorporate, work and relaxation, associations, traditions, exercises, systems.

Ideas that he specified has been comprise of these occasions: political and regulatory, religious creative. Signals and Habits are other events that he pondered. He presented logical variables for interpretation process which include: Purpose of content, inspiration and social, specialized and semantic level of readership, significance of referent in SL content setting, regime of word and referent, future or referent. He energize doubtlessly communicated that operationally he doesn't consider dialect to be a section or feature of culture in opposition to the view taken by Vermeer who communicated that "dialect is a bit of a culture" (Newmark, 1989, p. 222). As indicated by Newmark, Vermeer's state of mind would recommend the inconceivability to interpret though for the last mentioned, deciphering the source language (SL) into a helpful type of TL is a piece of the interpreter's capacity in transcultural correspondence.

The importance of the translation process in communication led Newmark to proposed common language and culture may accordingly be viewed as being firmly related and the two perspectives must be considered for translations. While considering the interpretation of social words and thoughts, Newmark (1988) proposed two contradicting strategies: transference and componential analysis. As per him transference gives 'local color' keeping social names and ideas. In spite of the fact that setting the accentuation on culture, significant to start peruses, he asserted this strategy may cause issues for the general readership and breaking point the cognizance of specific viewpoints. Newmark (1988) likewise expressed the significance of componential analysis in translation as an adaptable yet methodical technique for spanning the various lexical crevices, both phonetic and social, between one language and another.

The meaning of clarification as footnote is that, the interpreter may wish to give additional data to the TL peruses. He would clarify this additional data in a footnote. It might come at the base of the page, toward the finish of section or toward the finish of the book. Cultural equivalent is the SL social word is interpreted by TL social word. Compensation is a method which is utilized while standing up to lost significance, sound impact, businesslike impact or representation in one a player in content. The word or idea is remunerated in other piece of the content.

Newmark has been investigated for his strong prescriptivism, and the dialect of his appraisals still bears insights of what he himself calls the "pre-phonetics time" of understanding looks at: translations are "smooth" or "lumbering", while elucidation itself is a "workmanship" (if semantic) or a "scarf" (if informative). Regardless, the huge number of cases in Newmark's work gives satisfactory course and insight to the understudy and a substantial bit of the request he handles are of basic rational significance to understanding (see furthermore, Newmark, 1993).

In House's model register covers an assortment of components, some of which are extra to those explicitly expressed by Halliday. Field alludes to the topic and social activity and spreads the specificity of lexical things. Tenor incorporates the addresser's transient, geological and social provenance and in addition his or her intelligent person, passionate or full of feeling position his or her "own perspective". "Social disposition" alludes to formal, consultative or casual style. There is a component of House's (1997) demonstrate works as, individual printed work that is separated to enlist and class. Enroll include, field tenor and mode. Field is topic and social activity. Tenor incorporates member relationship, creator's provenance and position, social part relationship, social state of mind. Mode contains medium (simple/complex), interest (simple/complex). Field, mode and tenor are in the language or content.

The individual content capacity can't, in any case, be the same for TT and ST since House's (1997) show works include, a profile is made of the ST register. To this is incorporated a depiction of the ST genre recognized by the register. Together, this allows an 'announcement of capacity' to be made for the ST, including the ideational and social piece of that limit (at the end of the day, what information is being passed on and what the relationship is among sender and recipient). The same entrancing technique is then accomplished for the TT. The TT profile is appeared differently in relation to the ST profile and a declaration of "mismatches" or oversights is conveyed, masterminded by genre and to the situational estimations of register and genre; these dimensional bumbles are insinuated as secretly wrong's to remember them from "clearly incorrect blunders", which are denotative frustrates or target structure mistakes. An "announcement of value" is then made of the interpretation. Finally, the interpretation can be requested into one of two sorts: clear interpretation or mystery 
interpretation.

An overt translation is a TT that does not imply to be an original. In House's (1997) rather befuddling definition "an overt translation is one in which the addressees of the translation text are "overtly" not being straightforwardly tended to" (House, 1997 p. 66). An in secret interpretation "is an interpretation which acknowledges the status of a special source message in the goal culture". The ST is not associated particularly to the ST culture or gathering of group of onlookers; both ST and TT address their different authorities clearly. "The limit of a clandestine unique is to repeat, emulate or address in the deciphered content the limit the first has in its lingual social framework and talk world" (House, 1997 p. 114). It does this without taking the TT scrutinizes into the discussion universe of the ST.

In this way, proportionality is crucial at the level of genre and the individual content limit, yet what House (1997) called a "cultural filter" ought to be associated by the interpreter, modifying social parts and along these lines giving the inclination that the TT is a unique. This may incorporate changes at the levels of dialect content and register. House (1997) discussed the significance of cultural filter with respect to German-English relative sensible examinations which she has driven and gives instances of different practices in the two social orders that ought to be reflected in interpretation. For instance, she found that German tends to lean toward a more clear substance focus, while English is more social. This would be reflected in undercover interpretations, the letter from the association official being more social in English, for instance. House brought up the way that the "overt"- "covert" interpretation refinement is a cline instead of a couple of parallel alternate extremes. Besides, in situations where secretively practical equality is wanted however where the ST type does not exist in the objective culture, the point ought to be to create a clandestine form instead of an undercover interpretation.

Newmark's (1988) grouping of CSIs and House's (1997) display has been embraced as the theoretical framework of this examination. Social perspectives are of foremost significance in interpretation examines. This issue draws in the consideration of numerous researchers in a way that can state social level headed dialogs are one of the central issues in "translatology". Talking about the elucidation of CSIs is moreover faulty, since a lone unclear word or articulation may be deciphered in different courses by different interpreters. In any case, what is basic is the course of action of an interpreter standing up to CSIs in the substance for finding their legitimate significance and a sensible indistinguishable for these things in the TT. Thusly it is basic for interpreters to be familiar with different strategies and approaches in overseeing CSIs. Based on what was mentioned above, this study tried to find logical answers to the following questions.

1). Which translation strategies of House's (1997) model have been employed by Persian translation of Waiting for Godot by Alizad and Rastgar?

2.) Which translation strategy can be decided as the most adequate in translation of culture-specific texts?

\section{Method}

\subsection{Materials}

The materials which were used in this study consisted of Waiting for Godot based on Newmark (1988) strategies and House's (1997) model and its Persian translation by Alizad \& Rastgar. House's (1997) model, that used in this study is based on Halidayan theory display which is a precise complexity of a original and its rendering on three contrastive levels: the levels of language/text, register (filed, tenor and mode) and genre. Regisrter is arranged into three sections: Filed alludes to the topic and social activity, tenor incorporates the partner relationship. It includes the creator's provenance and position, social part relationship and social mentality. The last one as a mode identifies with channel and the level of relationship amongst addresser and recipient. Rastgar's version appeared in $(1393,2014)$. He is a prolific translator especially of drama, famous - may be notorious - for the great extent of freedom that he exerts in translation. He uses as many Persian informal elements and cultural items as in his translation to make it domesticated and native in TL. It appears that Rastgar has a good knowledge of English as well as informal and spoken Persian, but exaggerates in the use of informal language.

Alizad's translation first appeared in $(1380,2001)$. It was then enacted in theaters in Tehran in 1385, 2006, the third edition was published with same modifications. Alizad believes his translation received welcome by readers and especially the academia because of its performance capacities $(1385$, p. 9). Revisions of the translation were generally based on the feedback of the actors of Waiting for Godot in the rehearsal (Ibid). The translation is close to the original as the method used by Alizad is semantic translation (Newmark 1988).

In fact, translating a foreign text and making it acceptable by the target language audience is not an easy task because each text has its own characteristics in language use, word choice, cultural concepts, and so forth. 
Therefore, when the text is translated into another language, certain factors should be considered. Since the source text is translated for a commercial purpose, the translator has to translate it as quick as possible in order to respond to the target audience's demands. Consequently, many people have doubted about the quality of the translation. There are many literary works that have translated into other languages and suffered for their quality from linguistic, semantic, pragmatic, and stylistic point of view.

Numerous translations scholars have attempted to characterize culture. Newmark considered "culture to be the lifestyle and its sign to utilizes a specific dialect as its methods for articulation finding the best identical for culture particular things in interpretation is one of the principle worries for every interpreter" (Newmark, 1998, p. 94). Interpretation as characterized by Miremadi "is a corresponding procedure from one culture to the next and from different societies into one culture. As it were, there is a give-and-take process" (Miremadi, 1993, p. 23). In this procedure, interpreters manage some non-proportional words for which they should locate a suitable equal. The interpreters need to locate a proportional with a similar idea in the objective content TT. In situations where ideas are not indistinguishable, they can't be utilized reciprocally in even two vernaculars of a similar dialect. "There are many words in each dialect for which there is no full equivalent in the TT" (Jacobson, 1959, 2000).

A standout amongst the most troublesome issues an translator confront is the manner by which to discover lexical counterparts for the regions and angles which are not known in the receptor culture, there is not a comparing word or expression in the receptor language effortlessly accessible for the translators. A translator needs to consider the two languages as well as the two societies, since there will be a few ideas in the source language, which don't have lexical counterparts in the objective language. "This might be because of contrast of geology, traditions, convictions, perspective, and different factors Even if close reciprocals are discovered, they can once in a while uncover and pass on the very same back rubs" (Larson, 1998, p. 163). At times, there are a few words or expressions in one dialect which are obscure for another language. This marvel is called "semantic void or lexical gap" (Gambier, 2004). In their speculation of semantic relativity Sapir and Wolf additionally hold that "he dialect we talk the two effects and mirror our perspective of the world" (Armstrong, 2005, p. 16). In a prominent 1940 article, Whorf alluded to Eskimo dialects having seven particular words for snow. In a few groups, this idea might not have been lexicalized.

For instance in a few sections of the world the occupants have not seen snow, consequently they don't have any word to convey the idea. Clearly every group has its own CSIs particular to its language. Each word or articulation may allude to an idea which is unique in relation to one dialect to another. For instance, pig or owl may have the same denotative and word reference importance in various languages, however they may pass on entirely unexpected and even inverse faculties in two unique languages relying upon the way of life of the general public. It is fundamental for an expert interpreter and even the understudies of interpretation to know about social contrasts. Interpreters ought to have the capacity to discover a scope of potential outcomes that incorporate every one of the diversities of interpretation procedures which can be utilized to tackle the issues of deciphering CSIs between languages.

There are distinctive techniques embraced by interpreters for deciphering CSIs. A few people may trust that we can't decipher CSIs, since they are identified with a particular culture. Be that as it may, Baker trusted that "figures of speech and settled articulations which contain culture-particular things are not really reasonable It is not the particular things an articulation contains yet rather the importance it passes on and its relationship with culture-particular setting which can make it justifiable or hard to decipher" (Baker, 1992, p. 68). In view of this announcement, the interpretation of CSI is certainly feasible, but instead entangled for the interpreter. Despite the fact that the interpreter should attempt to pass on both shape and significance, their objective is "to keep the importance consistent and some of the time the receptor dialect frame ought to be changed all together that the source dialect importance not be misshaped" (Larson, 1998, p. 12). Moreover, Nida (1964) specified that at whatever point there is a "contention" amongst shape and substance. "Correspondence in significance must have need over correspondence in style" (Munday, 2009, p. 42). Consequently in the translations of CSIs the translator tries to concentrate on passing on the significance, not the shape. As such, in the translation of these examples the need is the importance. Figures of speech were considered as a subdivision of CSIs since they reflect parts of the life of the TL speakers. Diverse researchers have broken down the methodologies and methodology required in the translation of CSIs, recommending different arrangements of such systems. One of the pioneers in this field was Newmark (1988).

He proposed various methods for translation CSIs, in particular transference, naturalization, cultural equivalence, functional equivalence, descriptive equivalence, synonymy, through-translation, shift or transposition, modulation, recognized translation, translation label, compensation, componential analysis, reduction and expansion, paraphrase, couplet, and notes. In later examinations some different classifications have been 
proposed for such techniques.

Graedler (2000), watched translators applying such strategies as: making up another word, choosing a word in the TL which appears to be like or has an indistinguishable importance from the SL expression, protecting the SL expression in place, clarifying the significance of the SL articulation as opposed to deciphering it. Pederson (2005) utilized the word rendering as opposed to deciphering and furthermore the term additional semantic Culture-bound Reference ECR rather than Culture Specific Item CSI. As per Pedersen, "culture-bound terms might be intra etymological and additional phonetic culture-bound references. In light of Pederson's announcement, systems for rendering additional semantic CSIs are SL arranged and TL situated" (Pederson, 2005, pp. 3-9).

\subsection{Procedures}

\subsubsection{Data Collection Procedures}

The methodology of this study was an expressive interpretive examination of the ST and the TT. Newmark's (1988) order of CSIs was gotten as the hypothetical structure of this investigation. This study went for doing an investigation of the CSIs in Waiting for Godot, distinguishing and depicting procedures proposed by Newmark (1988) to adapt to CSIs, and assessed by House's (1997) to discover the recurrence of each. In this examination, it was the setting which decided the unit of investigation. Along these lines, the unit of examination could be a word, an expression, or a sentence. The system of the present examination was begun with perusing the ST (unique abstract content) for discovering CSIs as indicated by Newmark's arrangement, perusing the TT (the interpretations by Alizad \& Rastghar) keeping in mind the end goal to discover interpretation of CSIs, and afterward, contrasting the TT and the ST for separating House's (1997) translations techniques connected in the English translations of CSIs. Every strategy was represented by cases for a superior comprehension. For better understanding exploration strategy is characterized and outlined by cases in tables 1-7:

Table 1. Examples of transference applied in translating of waiting for godot

\begin{tabular}{|c|c|c|}
\hline Source text & Alizad's & Rastgar's \\
\hline Francs & دو شيلينگ & صدفر انك \\
\hline Picnic basket & سبد بيكى نيك & سبد سفرى \\
\hline Atlas, son of Jupiter & اطلس ابن زوييتر & اطلس بِرزوييتر \\
\hline
\end{tabular}

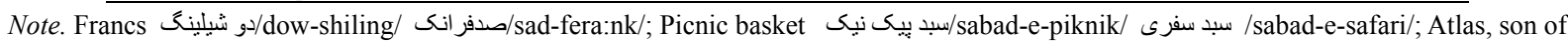
Jupiter اطلس ابن زوبيتيتر/atlas pesar-e-zhoopiter.

About the word Atlas, son of Jupiter, Atlas and Jupiter are cultural words, Greek mythology, not known by many Iranian readers. They need therefore a footnote to be clarified for them

Table 2. Examples of cultural equivalent applied in translating of waiting for godot

\begin{tabular}{|c|c|c|}
\hline Source text & Alizad's & Rastgar's \\
\hline His Highness & حضرت اشرف & حضرت اجل \\
\hline Our Savior & ل & منجى مان \\
\hline
\end{tabular}

Note. His Highness حضرت اشرف/hazrat-e-ashraf/ حضرت اجل/hazrat-e-ajal/; Our Savior ناجى ملى مان/naaji-ye-maa/ منجى مان/mownji-ye-maan/.

The word "his highness" is in social culture classification and Rastgar and Alizad translated this word in cultural equivalent strategy. Both Persian equivalents are used in the same situation to people of a higher rank. Apparently there is no problem with the translation of the word "our savior". However, the fact is that the 'Savior' of Christian is Holy Christ and that of Iranian Shiites is Mahdi the Lord of our age.

Table 3. Examples of modulation applied in translating of waiting for godot

\begin{tabular}{|c|c|c|}
\hline Source text & Target text (Alizad) & Target text(Rastgar) \\
\hline In the nineties & اواخر قرن نوزدهم & س سال هاى نود \\
\hline
\end{tabular}

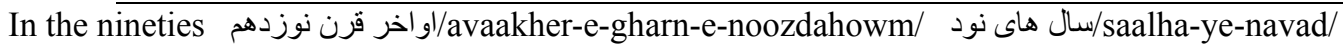

The phrase "in the nineties" is classified as organization, customs, activities, procedures, concepts. Rastgar 
translated this phrase in modulation, descriptive equivalent instead Alizad translated it in literal translation. Alizad's translation is ambiguous for Iranian Readers that are not well acquainted with western calendar. In Rastgar's translation, it is disambiguated by modulation or giving a descriptive equivalent, though قرن نوزدهم (avahker gharn noozdahom) may cover more than one decade.

Table 4. Examples of Componential analysis applied in translating of waiting for godot

\begin{tabular}{lll}
\hline Source text & Target text (Alizad) & Target text(Rastgar) \\
\hline Pan sleeps & خداى مر اتع هم خوابيده \\
\hline
\end{tabular}

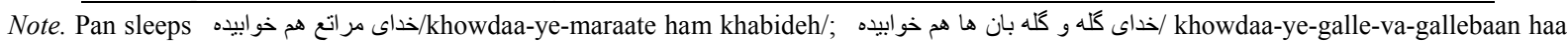
ham khabideh/.

The word "pan sleeps", a cultural word in Greek mythology, is the good of wild, shepherds and flocks. Both translators made a componential analysis

Table 5. Examples of Literal Translation applied in translating of waiting for godot

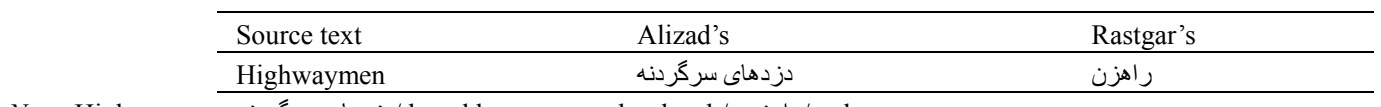

Note. Highwaymen دزدهاى سركَردنه/douzd ha ye sar-e-ghardaneh/ دزدردنه/raah zan.

Table 6. Examples of Recognized Translation applied in translating of waiting for godot

\begin{tabular}{|c|c|c|}
\hline Source text & Alizad's & Rastgar's \\
\hline Holy Land & ارض مقدس & ارض مقدس \\
\hline
\end{tabular}

The "Holy land", classified as organization, customs, and both translators choice recognized translation strategy for translation it. ارض مقدس (arz-e- moghadas) maybe not known to many readers. It would therefore be ideal to give a note or gloss- the last strategy in Newmark (1988).

Table 7. Examples of Functional Equivalent applied in translating of waiting for godot

\begin{tabular}{|c|c|c|}
\hline Source text & Alizad's & Rastgar's \\
\hline Highwaymen & دزدهاى سركردنه & راهزن \\
\hline Picnic basket & سبد بِيك نيك & سبد سفرى \\
\hline
\end{tabular}

Note. "Picnic basket" سبد سفرى/sabad-e-safari/ is not common in Persian, while نيك بيك (picnic), the borrowed word from English, is used naturally.

"False friends (faux Amis in French) are word pairs from different languages which in spite of similarities in form have different meaning" (Bassman, 1998, p. 405). For example, French "demander" is translated in to English as to "request" not to "demand" and English "cold" changes in to Italian "caldo" (warm) not "cold". Frequently, such similarities in form, lead to interference errors in language learning and translating.

\subsubsection{Data Analysis Procedures}

As the first step, the researcher read the ST paying attention to and focusing on Newmark's (1988) spaces for CSIs incorporate biology, material culture, social culture, associations, traditions, exercises, strategies, ideas, signal and propensities. Then, she found CSIs, and then, she determined the domain of them. In fact, Newmark's five domains of CSIs were used as a filter for detecting culture After reading the ST, the researcher read the TT, as well, and then, she found the translation of the CSIs in the TT.

Therefore, CSIs were detected in the ST, and then, their equivalents in the TT were checked. After that, CSIs of two Persian translations of Waiting for Godot were assessed by House's (1997) model. After the data was collected, the proportions of the strategies were analyzed. The analysis of the corpus of data allowed us to make some generalizations about, first, the translator's disposition to use one strategy more than others in order to render CSIs, and second the translator's desire for the frequency of use of different strategies. 


\section{Results}

As the results of the study according to table 8 showed, Alizad has applied synonymy in translation more than other strategies, according to Newmark (1998), synonymy is used as a compromise when there is no clear one-to-one and equivalent between the TL and SL word. As stated by Newmark (1998), a synonymy is just proper where exacting interpretation is unrealistic and in light of the fact that the word is not sufficiently essential for componential investigation. Therefor it can be argued that Alizad used synonymy to avoid literal translation, which could distort the fluency of TT. Rastgar has applied cultural equivalent more than other strategies. Both translators have used many strategies in translating cultural items. Some are more frequent, while some are rare.

Table 8. Frequency and percentage of each applied strategy (Alizad's translation)

\begin{tabular}{lll}
\hline Translating & Number of Items & Found Percentage (\%) \\
\hline Transference & 3 & 9.4 \\
Naturalization & 0 & 0 \\
Cultural Equivalent & 3 & 9.4 \\
Functional Equivalent & 0 & 0 \\
Descriptive Equivalent & 0 & 0 \\
Componential Analysis & 0 & 0 \\
Synonymy & 29 & 87 \\
Through- Translation & 0 & 0 \\
Shift or Transposition & 0 & 0 \\
Recognized Translation & 1 & 3.1 \\
Compensation & 1 & 3.1 \\
Modulation & 1 & 3.1 \\
Paraphrase & 0 & 0 \\
Notes & 0 & 0 \\
Total & 38 & 115 \\
\hline
\end{tabular}

Table 9. Frequency and percentage of each applied strategy (Rastgar's translation)

\begin{tabular}{lll}
\hline Translating Strategy & Number of Items & Found Percentage (\%) \\
\hline Transference & 3 & 9.4 \\
Naturalization & 0 & 0 \\
Cultural Equivalent & 8 & 24 \\
Functional Equivalent & 2 & 6 \\
Descriptive Equivalent & 0 & 0 \\
Componential Analysis & 0 & 0 \\
Synonymy & 2 & 6 \\
Through- Translation & 0 & 0 \\
Shift or Transposition & 0 & 0 \\
Recognized Translation & 1 & 3.1 \\
Compensation & 1 & 3.1 \\
Modulation & 0 & 0 \\
Paraphrase & 0 & 0 \\
Notes & 0 & 0 \\
Total & 17 & 51.51 \\
\hline
\end{tabular}

\section{Discussion}

The extent of the use of descriptive equivalents, componential analysis, and recognized translation are relatively low. Euphemism is seen because of cultural limitation in the target language. Some cases of mistranslation are detected. Communicative translation is clearly significant in Rastgar's version, while the main strategy of Alizad is semantic translation. It should be noted that couplets a combination of two or more translation strategy is worth considering. Languages are not isomorphic. There are many linguistic and cultural differences between them. CSIs can be said to pose greater difficulties for translators even for well-versed translators. "Language and culture have close relationships and interacts with each other. Translation as a product and translation as an act cannot be separated from the concept of culture" (Hashemi-Minabad, 1387, p. 69).

Translation studies scholars as early as Nida (1964) has dealt with the culture and culture specific items in 
translation. There are many definitions and classifications for cultural items as well as strategies for their translation. In this study, Newmark's classification and strategies (1981) were used to analyze the data. Strategies proposed by Ivir (1987) as well as some general concepts on translation studies on the subject were also used as supporting elements. The study was based on House's (1997) model of translation quality assessment. There was a controversy over the translation approach of Rastgar, because of his informal language and the great extent of his undue additional to and alternation of the original. After translation many dramatic works of Ibsen (1826-1906) Norwegian playwright, began translating Becket's work.

Alizad (1381) in an article appeared in a widely- circulated newspaper- Iran-bitterly criticized Rastgars translation of Waiting for Godot. He believed Rastgar had reduced the original, which is one of the masterpieces of world literature, to slapstick- a low comedy, "rouhowzi" in the Persian which is somehow pejorative. Alizad, by giving some example of low translation of Rastgar, compered them whit his own translation, seldom giving the original English words. The main theme of Alizad's article, apart from his sharp critics of Rastgar, is that many Persian translations of dramatic works are not fit for "performing on stage" and lack "the capacity to be fluently performed". "He believed those translations are only for reading not acting on the stage", like closet drama- "a play designed to be read rather than performed" (Cuddon \& Habib, 2013, p. 130).

Data analysis of this study showed that Alizad's translation is clearly overt. In an article on criticizing Rastgar's translation of Waiting for Godot as well as denouncing many other translation of dramatic literature (1381), he emphasized on his overt following House's (1997) model and semantic following Nida (1964) translation strategies. Based on data analysis Rastgar's translation is covert in the extent that it is an example of domestication. Some writers including Alizad condemn Rastgar for making his translation as purely native.

The adequating of a translation strategy depends on the case in point. The context and situation of a cultural item as well as the methodology of a translator determines the choice of strategies. Obviously the most frequently used strategies can be regarded as the most adequate in rendering CSIs in Waiting for Godot. However, because of the overuse of Rastgar in giving CSIs in his translation, the results cannot be generalized to a normal translation under study. Leaving aside Rastgar's excessive use of certain elements, the most adequate translation strategies for CSIs can be suggested as cultural equivalents, synonymy and transference.

About the translations of poem, both translators had different strategies. The poem is in the style of English nursery rhymes. Alizad's translation is linguistically and culturally equivalent to the original. This translation follows the style of Low-Legged Yellow Henدباكوتا مرغ زورمد (Morgh-e-zard-e-pakoota) sometimes included in Water Came...Which Water? آب كلوم اومد آب. It begins as:

$$
\text { يه مرغ زردى داشت }
$$

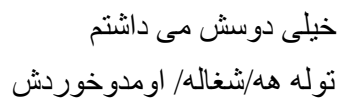

Ye morgh-e-zardi dashtam

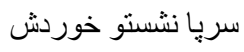

Kheyli doosesh midashtam

Toole he/ shoghale / omad-o-bordesh

Sarpa neshast-o-khordesh

(Shamlou, 1357, Vo. 1, p. 15P)

On the other hand, although Rastgar has a great tendency toward the use of colloquial and informal language, leading generally into an excess, his translation is unexpectedly formal. It should be noted that both translators have made some modification, additions and deletions. For example in two translation of this phrase, (A dog came in), Alizad's آثنبزما يه سح داشت (Aashpaze ma ye sag dasht), Rastgar's, آو اره سحى به مطبخى رفت (avareh sagi be matbakhi raft) and their back translations, Alizad's (Our cook had a dog), Rastgar's (In went a wondering dog to a kitchen) and this words, (A crust of bread)Alizad's يه تيكه كوشت (Ye tikeh ghoosht), Rastgar's اون سكوخيلى (Oon sago kheili doos midash), addition is happened. After that in the phrase (All the dogs come running Rastgar has deleted this line.

\section{Conclusion}

It can be finished up from the information got that propositions interpreters have utilized the greater part of Newmark's interpretation systems for CSIs to render Waiting for Godot effectively. From among Newmark's (1988) rundown of techniques, synonymy was the most as often as possible utilized system in deciphering the CSIs by Alizad, and the most frequently strategy used by Rastgar was cultural equivalent. Modulation, 
recognized translation and compensation were the least frequently used strategies.

At long last, modulation and pharaphrase together involved a similar point toward the end. As stated before, the strategies proposed by Newmark's (1988) for translating CSIs were mainly used in this study. However, in some case they not sufficient for analysis. Therefore, other strategies are needed to adequately analyze the data, for example those proposed by Ivir (1987). It should be noted that in investigating translations that use Alizad \& Rastgar's methodologies it seems to resort to other concepts of translation studies as domestication and foreignization (Venuti, 1995, 2005).

\section{References}

Aixela, J. F. (1996). Culture-specific items in translation. In R. Alvarez \& M. Carmen-Africa Vidal (Eds.), Translation, power, subversion (pp. 52-78). Clevedon: Multilingual Matters.

Akbari, M. T. et al. (1993). A glossary of islamic technical terms, English-Persian. Mashhad: Islamic Research Foundation.

Alizad, A. (1381). Reading Waiting for godot as a slapstick. Iran newspaper, No. 2095.

Alizad, A. (2001). Waiting for godot (In Persian). Tehran: Bidgol.

Armstrong, N. (2005). Translation, linguistics, culture: A French-English handbook. Clevedon: Multilingual Matters.

Baker, M. (1992). In other words: A course book on translation. London: Routledge. https://doi.org/10.4324/9780203327579

Baker, M. (Ed.). (2009). Routledge encyclopedia of translation studies. London: Routledge.

Baker, M., \& Saldanha, G. (Eds.). (2009). Routledge encyclopedia of translation studies. London: Routledge, Taylor \& Francis e-Library.

Bassnett, S. (2002). Translation studies. London: Routledge.

Becket, S. (1959). Waiting for Godot, (In Persian).Translators: Alizad (2001) and Rastgar (2014). Tehran: Bidgol and Ngah.

Brown, K., \& Miller, J. (2013). The cambridge dictionary of linguistics. Cambridge: Cambridge University Press. https://doi.org/10.1017/CBO9781139049412

Bush, P. (1998). literary translation. In M. Baker (Ed.), Routledge encyclopedia of Translation studies (pp. 127-130). London: Routledge.

Bussmann, H. (1998). Rutledge Dictionary of Language and Linguistics. London and New York: Routelge.

Cambridge Dictionaries Online. (2011). Retrieved http://dictionary.cambridge.org/dictionary/english/culture

Chadwick. (2011). Anthony. Waiting for Godot. Retrieved from $\mathrm{http}: / /$ catholicusanglicanus.wordpress.com//waiting-for-godot

Chappelle, C. (2013), the encyclopedia of applied linguistics. London: Wiley-Blackwell.

Cluver, A. (1992). Trends in the changes of translating domains: an overview.

Crystal, D. (2008). A dictionary of linguistics and phonetics. Malden: Blackwell. https://doi.org/10.1002/9781444302776

Cuddon, J. A., \& Habib, M. A. R. (2013) a dictionary of literary terms and literary theory. West Sussex: Wiley-Blackwell.

Culture. In Merriam-Webster's Online Dictionary (11th ed.). Retrieved from http://www.merriam-webster.com/dictionary/culture

Dabaghi, A., \& Bagheri, M. (2012). The issue of translating culture: A literary case in focus. Theory and Practice in Language Studies, 2(1), 183-186. https://doi.org/10.4304/tpls.2.1.183-186

Dryai, M. R. (1374). Islamic Terminology. Tehran Islamic Research Foundation.

Esslin, M. (1961). The Theatre of the Absurd. London: Methuen Publishing Limited.

Gambier, Y., Miriam, S., \& Radegundis, S. (2004). Doubts and directions in translation studies. The Netherlands: John Benjamins. 
Graedler, A. L. (2000). Cultural shock. Retrieved from http://www.hf.uio.no/iba/netkurs

Grigas, R. (1995). Destiny of the Nation. Vilnius: Rosma.

Hafiz, I. S. (2006). The Divan-I Hafiz. translated by Wilberforce Clarke. Tehran: Samir Pblication.

Harvey, M. (2000). A beginner's course in legal translation: The case of culture-bound terms. Retrieved from http://www.tradulex.com/Actes2000/harvey.pdf

Hassani, S. (2010). Culture specific items in translation: The case of Chardin's Travelogue. Retrieved from http://srbiau.ac.ir/Files/ABSTRACT-language/22941.pdf

Hatim, B. (2014) Teaching and Researching Translation. London and NewYork: Routledge.

Hatim, B., \& Mason, I. (1997). The translator as communicator. London: Routledge.

Hatim, B., \& Munday, J. (2004). Translation: An advanced source book. London: Routledge.

Hermans, T. (Ed.) (2014). The manipulation of literature: Studies in literary translation. New York: Routledge.

Hervey, S. G. J., \& Higgins, I. (1992). Thinking Translation: A course in translation method, French-English. New York: Taylor \& Francis Routledge.

Hosseini, M. S. M., \& Davtalab, H. (2011). An analysis of culture-specific items in the Persian translation of Dubliners Based on Newmark's model. Theory and Practice in Language Studies, 1(12), 1767-1779.

House, J. (2009). Translation. Oxford: Oxford University Press.

Ivir, V. (1987). Procedures and strategies for the translation of culture. Indian Journal of Applied Linguistics, 13(2), 35-46.

Jakobson, R. (1959/2000). On linguistics aspects and translation (pp. 113-118). In L. Venuti (Ed.).

Khodaparasti, F. (1385). Islamic Science Dictionary Persian- English. Tehran: Farhang Moaser.

Kolawole, S. O., \& Salawu, A. (2008). The literary translator and the concept of fidelity: Kirkup's translation of CamaraLaye's L'Enfant noir as a case study. Translation Journal, 12(4). Retrieved from http://translationjournal.net/journal/46lit.htm

Kramsch, C. (1998). Language and culture. Oxford: Oxford University Press.

Larson, M. L. (1998). Meaning-based translation: A guide to cross-language equivalence. New York: University Press of America, Inc.

Lefevere, A. (Ed.). (2003). Translation/history/culture: A sourcebook. New York: Routledge, Taylor \& Francis e-Library.

Lorscher, W. (1996). A psycho linguistic analysis of translation processes. Meta, XLI, 1, 26-32. https://doi.org/10.7202/003518ar

MC Arthur, T. (1992). The Oxford Companion to the English Language. Oxford: Oxford University Press.

Miremadi, S. A. (1991). Theories of translation and interpretation. Tehran: SAMT.

Munday, J. (2008). Style and Idology in Translation. London and New York: Routledge.

Munday, J. (2009). A Routledge companion to translation studies. New York: Routledge.

Munday, J. (Ed.). (2009). The Routledge Companion to Translation Studies. London: Routledge.

Munday, J. (Ed.). (2010). introducing translation studies: Theories and applications. London: Routledge.

Newmark, P. (1988). A textbook of translation. Hertfordshire: Prentice Hall.

Newmark, P. (1991). About translation. London: Multilingual Matters Ltd.

Newmark, P. (1995). Paragraphs on translation. London: Multilingual Matters Ltd.

Nida, E. (1964). Toward a Science of Translating: With Special Reference to Principles and Procedures Involved in Bible Translating. Netherland: Brill Academic Publishers.

Nida, E. A., \& Taber, C. R. (1969, 2004). The Theory and Practice of Translation. Shanghai: Foreign Language Educational Press.

OIk, H. (2003). Cultural knowledge in translation. ELT Journal, 57(2), 167-178. https://doi.org/10.1093/elt/57.2.167

Ordudari, M. (2007). Translation procedures, strategies, and methods. Translation Journal, 11(3). Retrieved from 
http://translationjournal.net/journal/41 culture.htm

Paluszkiewicz-Misiaczek, M. (2005). Strategies and methods in dealing with culture expressions on the basis of Polish-English translations of certain administrative and institutional terms. Proceedings from the Eighth Conference of English, American and Canadian Studies: Linguistics, methodology and translation, 3, 243-248. Masaryk University.

Pedersen, J. (2005). How is culture rendered in subtitles?

Ping, K. (2004). Culturaltranslation, 23. By Mizani, S, MA Translation Studies. Retrieved from http://www.translationdirectory.com/articles/article1507.php

Plotkin, H. (2001). Some Elements of a Science of Culture. In W. Harvey (Ed.), The Debated Mind. Evolutionary Psychology versus Ethnography (pp. 91-109). Oxford, New York: Berg.

Plumbo, G. (2009). Key Terms in Translation Studies. London: Continuum.

Rastgar, A. (2014). Waiting for godot (In Persian). Tehran: Negah.

Salehi, M. (2013). Strategies applied by native and nonnative translators to transfer Persian culture-specific items: A case study on an Iranian novel. Journal of Academic and Applied Studies, 3(4), 1-17.

Samei, H. (1393) Word Formation Pattern in Persian. Tehran: Academy of Persian Language and Literature.

Samimi, M. R., \& Abbasi, P. (2014). Cultural presuppositions in translation from Persian into English: A case study of two Persian novels: The Blind Owl and the School Principal. The Criterion: An International Journal in English, 5(2), 467-480.

Scarino, A., \& Liddicoat, A. J. (2009). Teaching and Learning Languages. A Guide. Melbourne Curriculum Corporation of Australia.

Scarino, A., \& Liddicoat, A. J. (2009). Teaching and learning languages: A guide. Carlton South: Commonwealth of Australia.

Shamlu, A. (1375). Ketab-e Khuche (the book of Street). Tehran: Mazyar.

Shirvani, M. R. (1383). Dictionary of Persian Morphology. Tehran: Aghah.

Shokri, S., \& Ketabi, S. (2015). Translating culture-specific items in Shazdeh Ehtejab: Examining foreignization and domestication. International Journal of Research Studies in Education, 4(3), 3-16. https://doi.org/10.5861/ijrse.2015.1027

Siegrühn, A. (1992). Community translation. In A. Kruger (Ed.), Changes in translating domains (pp. 33-36). Pretoria: UNISA.

Snell-Hornby, M. (1988). Translation studies: an integrated approach. Amsterdam: John Benjamins Publishing Company. https://doi.org/10.1075/z.38

Tobias, S. (2006). Culture-specific items in Japanese-English literary translation: Comparing two translations of KawabatasIzu no Odoriko. Monash university linguistics Papers, 5, 27-35.

Venuti, L. (1995). The translator's invisibility. A history of translation. London: Routledge. https://doi.org/10.4324/9780203360064

Venuti, L. (1998). Strategies of translation. In M. Baker (Ed.), Encyclopedia oftranslation studies (pp. 240-244). New York: Routledge.

Venuti, L. (Ed.). (2004). The translation studies reader. London and New York: Taylor\& Francis Routledg.

Wiersema (2004). Global is ationand Translation. Retrieved from http://translationjournal.net/journal//27liter.htm

Wierzbicka, A. (1997). Understanding cultures through their key words: English, Russian, Polish, German, and Japanese. New York: Oxford University Press.

\section{Copyrights}

Copyright for this article is retained by the author(s), with first publication rights granted to the journal.

This is an open-access article distributed under the terms and conditions of the Creative Commons Attribution license (http://creativecommons.org/licenses/by/4.0/). 